\title{
Case of Study: Honey without Bees? Chemical Risks Associated to Sugarcane (Saccharum Officinarum) from Belo Horizonte, Brazil
}

\author{
Artur Canella Avelar \\ Laboratory of Rabbit Science, Department of Animal Science, Veterinary School, Federal University of Minas Gerais, Brazil
}

Copyright $\mathrm{C} 2016$ by authors, all rights reserved. Authors agree that this article remains permanently open access under the terms of the Creative Commons Attribution License 4.0 International License

\begin{abstract}
Sugarcane is one of the most important of raw materials used in manufactured food products. Its consumption is under public scrutiny for decades, always associated to cavities, obesity and diabetes. Sugary beverage portion sizes have exploded as high as 64 fluid ounces in some fast food chains in the USA. Meanwhile, anthropogenic activities such the application of arsenical pesticides has resulted in elevated (high as $900 \mathrm{~g}^{-\mathrm{g}^{-6}}$ ) levels of arsenic (As) in surface soils in many historic sugar cane areas of Hawaii, USA. To quantify simultaneously many elements as possible, it was applied the well-established nuclear analytical technique of Neutron Activation Analysis. Hazardous elements such As, Br, Na, some RREs (rare earth elements), Rb, Sc and $\mathrm{U}$ were detected and quantified in the product.
\end{abstract}

Keywords Arsenic, Uranium, Bromine, Lanthanum, Sucrose

\section{Introduction}

Sugarcane is a product extracted mainly from the plant Saccharum officinarum, belonging to the grass family Gramineae $^{1,2}$. Sugarcane offers a very condensed source of calories: an edible portion of 100 grams of sugar cane contains $380 \mathrm{kcal}^{3}$. Due to its sweet and pleasant flavor, the product is an often ingredient used in gum candies, cereal bars, juices, carbonated beverages, energy drinks, baked goods and several breakfast items. Practically everyone in the world consumes one or more forms of refined sugar each meal. Furthermore, sugar cane (as molasses) is plenty used in animal nutrition as an ingredient to increase palatability and energy to the final feed ${ }^{3}$.

Eighty percent of the world's sugar supply is derived from sugar cane, cultivated mostly in tropical climates in developing countries. The remaining twenty percent of the world's supply of sugar is derived from sugar beets, mainly cultivated in the northern hemisphere ${ }^{4}$.

Brazil is the leading sugar producer and the dominant player in the global trading of sugar. The country is considered the "price setter" on the world sugar market with international sugar prices set by the low production costs associated to produce sugar cane in Brazil ${ }^{5}$. The current forecast shows of Brazilian production of sugar cane within season $2012 / 13$ are 37.66 million tons, $4.72 \%$ more than in the previous season, which was 35.97 million tons. Out of this total $69.46 \%$ produced in the Southeast Region (including states of São Paulo - major producer, Minas Gerais - the second largest producer), $11.32 \%$ in the Northeast, $10.95 \%$ in the Midwest Region and $8.13 \%$ in the South ${ }^{6}$.

The world indicator price for raw sugar experienced a succession of peak and downward movements in 2010 before soaring to a 30-year high of USD \$36.08 cents/lb or USD $\$ 795.4 / \mathrm{t}$ in February 2011. By 2020-2021, the raw sugar price (Intercontinental Exchange) in nominal terms is expected at nearly USD $\$ 408 / \mathrm{t}$ or USD 18.5 cents $/ \mathrm{lb}^{5}$.

\subsection{Health Risk Associated to the Elevating Sugar Consumption}

In 2011, the American Heart Association published a statement that warned the fact of Americans consumed 22 teaspoons of sugar in daily basis. The document endorses that per capita consumption needs to come down to levels that should not be toxic ${ }^{7}$. The American Heart Association sustains that the best way to maintain a healthy weight and to decrease the risk of heart disease is to eat a healthy diet and to limit added sugar to no more than $100 / 150$ calories a day for women/for men. The limit sounds unrealistic in the era of large size beverages offer: serving cup sizes in fast-food chains are getting larger, leading to an enormous consumption of sugar mainly in infant and teenagers demographics. The trend toward larger portion sizes has occurred together with the prevalence of obesity and people becoming overweight in the west world. Serving sizes of 
manufacturer-packaged carbonated beverages have exploded - the original bottle size of the world leading soda drink was 6.5 fluid ounces. The same brand is found on market fourfold larger as portion seen on sale nowadays. Beverage portion sizes from the leading fast food (burgers) chains have increased more than fourfold since 1950s, from 7 fluid ounces to 32 fluid ounces. A sugary drink of this size contains 390 calories and almost no nutrients ${ }^{8,9}$.

In New York, the former mayor Michael Bloomberg has attempted to limit the size of sugary drinks. Seeking to reduce runaway obesity rates and deaths related to diabetes, the New York City Board of Health approved a ban on the sale of large sodas and other sugary drinks at restaurants, street carts and movie theaters. The rule has intended to bar the sale of sugary drinks in containers larger than 16 ounces 10. The ban was struck down in March 2013, and remains under debate and appeals in court ${ }^{11}$.

\subsection{Honey without Bees: An Historical Perspective of Sugar Cane and Slavery}

The plant is known to have been cultivated in New Guinea before 1000 BC. After a long journey a semi extensive culture was initiated in India and afterwards in China. The Indians devised the first techniques for extracting sugar from cane and called it "sarkara", a Sanskrit term from which the words for sugar in many European languages originate (açúcar, azúcar sucre, zucker, zucchero). It was in India, between the sixth and fourth centuries BC, that the Persians and the Greeks, discovered the famous "reeds that produce honey without bees" and brought sugar cane to the region from Middle East to Mediterranean Sea ${ }^{4}$. In the $14^{\text {th }}$ Century, Cyprus (followed decades later by Sicily) produced large amounts of sugar cane using labor of Syrian and Arab slaves 12 .

Iberians (from the Spanish side) started the modern exploitation of European Islands from the Canary Islands in 1312 by Malocello. In the following decades, the Castile Crown sponsored the profitable production of wine, sugar cane, sheep and cattle products in the Canary Islands. The commerce of these items expanded navigation and shipping farther South Atlantic ${ }^{12}$.

In the same way, Portuguese Crown copied the Canary's model based in slave workforce in the luso coast of Açores, Madeira, Cabo Verde and São Tomé, to produce wine, sugar cane, sheep and cattle products ${ }^{12}$.

By the end of $15^{\text {th }}$ Century, Iberians divided their strategies to expand their colonies: Portuguese searching for an eastward route to Asia and Spanish gambled on a westward route leaded by the Genovese Cap. Christopher Columbus, a sailor who previously worked in sugar cane plantation and slavery in North African Coast. Yet in 1492, date of discovery of America by Columbus, Pope Alexander VI issued a papal bull (bula pontificia) establishing the earth as the rightful property of the Roman Catholic Empires divided into regions to Portugal and Spain, accorded by the two Iberian nations in the treat named Tratado de Tordesilhas ${ }^{12}$.

Afterwards, sugar cane was firstly introduced in Brazilian tropical plantations by the Portuguese Crown in 1530's. Under Portuguese rule, the African coastline supplied slaves for colonial Brazil's sugarcane plantations. Slavery for Brazilian plantations was responsible for the exodus of millions of African men to South America (mostly to Brazil) in order to keep the sugar cane production running. Those slaves never returned to their homes in Africa. Hence, this exodus was the key fact for the formation of the Brazilian Society. Promptly the number of Africans outnumbered the number of Portuguese and natives. From XVII to XIX centuries, Portuguese men from the work class fathered more offspring with African slaves than with Portuguese women. Nowadays in the Brazilian Southeast, the majority of individuals are mix breed of Europeans, Africans (most of them from the slave heritage) and Indigenous forming the major population group of mulatos ${ }^{12,13}$.

Slavery was abolished in Brazil only in May 131888 ruled by the Princess-Impress Isabel (the last crowned head of Brazil). The Lei Aurea (Golden Law) gave an end to the most everlasting slavery in the free world. Additionally, early in the XX Century, coffee temporary replaced sugar cane as the major commodity (in US\$) in Brazilian trading ${ }^{6}$.

Recently Phillips ${ }^{14}$ wrote in The Guardian (London) regarding the sugar cane cutters labor situation in São Paulo

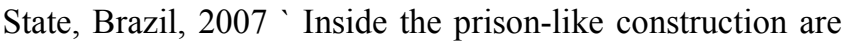
the cortadores de cana - sugar cane cutters - part of a destitute migrant workforce of about 200,000 men who help prop up Brazil's ethanol industry. (...) The "cortadores" cane cutters - are effectively slaves and complain that Brazil's cane industry is, in fact, a shadowy world of middle men and human rights abuses. (...) That includes working 12-hour shifts in scorching heat and earning just over US\$ 1 per ton of sugar cane cut, before returning to squalid, overcrowded "guest houses" rented to them at extortionate prices by unscrupulous landlords, often ex-sugar cutters themselves. (...)'. This modern slavery encountered nowadays in sugar cane plantations of Brazil and in South Asia is a conjunction of psychological manipulation and debt bondage, by which unfair loans to pay the subsistence and the worker round-trip to the farm keeping them perennially bonded to their employers ${ }^{15}$.

\subsection{Hazardous Substances in Sugar Cane Plantations}

Anthropogenic activities such the application of arsenical

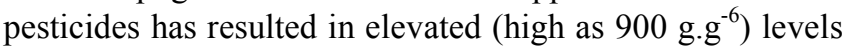
of arsenic (As) in surface soils in many historic sugarcane areas of Hawaii, USA ${ }^{16}$.

Rock phosphates applied as fertilizers in many crops present essential elements: calcium, phosphorus, manganese, selenium, sodium, and also hazardous elements such as uranium, thorium, arsenic, fluoride and elements with role to be determined such rubidium and the rare earth elements (the called RREs) ${ }^{17}$. 


\section{Objective}

To assess the concentration of multiple elements, including the most hazardous element in the world arsenic, in sugar cane Saccharum officinarum produced and commercialized in Brazil in order to verify the levels of essential, hazards and also of elements with role yet to be defined.

\section{Material and Methods}

\subsection{Analytical Technique}

The instrumental neutron activation analysis (INAA) technique is based on nuclear properties of the nucleus of the atom, radioactivity, and the interaction of radiation with matter. The simplest description of the technique says that when one natural element is submitted to a neutron flux, the reaction (neutron, gamma) occurs. The radionuclide formed emits gamma radiation, which can be measured by suitable equipment. About $70 \%$ of the elements have nuclides possessing properties suitable for neutron activation analysis. At the Nuclear Technology Development Centre (CDTN), Belo Horizonte, Brazil, it is located the nuclear reactor Triga Mark I IPR-R1 that allows the application of this technique 18,19 .

\subsubsection{Sampling}

It was taken randomized 5 commercial packs of sugar cane from local brands in local stores in Belo Horizonte, Minas Gerais State, Brazil. To quantify simultaneously many elements as possible, it was applied the well-established nuclear analytical technique of Neutron Activation Analysis ${ }^{18,19}$

The sugar cane samples were freeze-dried and lyophilized for 24 hours to eliminate their water content. Samples of each pack were isolated, weighed around $250 \mathrm{mg}$ and stored into polyethylene irradiation vials. They were irradiated in the reactor IPR-R 1 (CDTN/CNEN operating at $150 \mathrm{~kW}$ the thermal neutron flux is $6.6 \times 10^{11}$ neutrons $\mathrm{cm}^{2} \mathrm{~s}^{-1}$. The samples were irradiated simultaneously with gold foil comparators and reference material. Elemental contents were determined through two schemes of sample irradiations: 8 hours of irradiation to detect calcium, rubidium and uranium contents $^{16}, 4$ hours of irradiation to detect the remaining elements cited herein ${ }^{17}$ accordingly their half-lives as seen in Table 1.

After suitable decay time, the gamma spectroscopy was performed in a HPGe detector (hyper pure germanium semiconductor detector), $10 \%$ of efficiency, FWHM 1.85 $\mathrm{keV}$ and ${ }^{60} \mathrm{Co}, 1332 \mathrm{keV}$, connected to a multichannel analyzer. The calculations were processed using the Solcoy/KayZero Software ${ }^{18,19}$.

\subsubsection{Quality Control}

Triplicates of reference material Rice Flour (SRM 1568a, from National Institute of Standards and Technology, USA) were analyzed in order to verify the efficiency of the method and the traceability of element level determinations. Triplicates were weighed around $250 \mathrm{mg}$ (same mass of the samples) into polyethylene irradiation vials in order to be irradiated in the same batch of the sugar samples and monitors, each triplicate for an irradiation scheme (4 or $8 \mathrm{~h})$.

\section{Results: Presence of Some Selected Hazardous Elements in Sugarcane from the Local Market of Belo Horizonte, mMnas Gerais, Brazil}

\section{Quality Control}

For QA/QC purposes, a selected reference material: Rice Flour Reference Material SRM 1568a see data on Table 2 were used as three replicates (each irradiation batch was formed of 32 bone samples, samples of phosphate and one replicate of each SRM and k0-INAA standards). Batches were irradiated ways on Monday morning for 3 weeks in a row. SRM were analysed in order to verify the efficiency of the method and the traceability of element level determinations.

Table 1. Elemental composition of sugar cane from Brazil. N=5, dry weight

\begin{tabular}{|c|c|c|c|}
\hline Element & $\begin{array}{c}\text { Activation } \\
\text { Product }\end{array}$ & $\begin{array}{c}\text { Product } \\
\text { Half Life }\end{array}$ & $\begin{array}{c}\text { Elemental } \\
\text { Concentration }\left[\mathbf{g}^{-6}{ }^{-6}\right]\end{array}$ \\
\hline Arsenic & ${ }^{76} \mathrm{As}$ & 1.097 days & $0.81 \pm 0.10$ \\
\hline Bromine & ${ }^{82} \mathrm{Br}$ & 1.471 days & $16.8 \pm 1.54$ \\
\hline Calcium & ${ }^{47} \mathrm{Ca}$ & 4.536 days & $848 \pm 79$ \\
\hline Lanthanum & ${ }^{140} \mathrm{La}$ & 1.679 days & $0.53 \pm 0.06$ \\
\hline Sodium & ${ }^{24} \mathrm{Na}$ & 0.621 days & $262 \pm 30$ \\
\hline Rubidium & ${ }^{86} \mathrm{Rb}$ & 18.660 days & $31.7 \pm 6.2$ \\
\hline Scandium & ${ }^{46} \mathrm{Sc}$ & 3.410 days & $0.34 \pm 0.04$ \\
\hline Samarium & ${ }^{153} \mathrm{Sm}$ & 1.816 days & $0.12 \pm 0.02$ \\
\hline Uranium & ${ }^{239} \mathrm{~Np}$ & 2.355 days & $0.31 \pm 0.05$ \\
\hline
\end{tabular}

Table 2 data quality assessment: summarizes the concentrations for calcium, arsenic, rubidium and sodium determined in the certified reference material, Rice Flour (NIST-SRM 1568a) from National Institute of Standards and Technology, Gaithersburg, USA. A good agreement was found between the experimental and certified values.

Table 2. Elemental composition of Rice Flour Reference Material SRM 1568a. $\mathrm{N}=3$, dry weight

\begin{tabular}{|c|c|c|}
\hline Element & $\begin{array}{c}\text { Certified Value } \\
{\left[\mathbf{g . g}^{-6} \text { ] }\right.}\end{array}$ & Experimental Value $\left[\mathbf{g . g}^{-6}\right.$ ] \\
\hline Arsenic & $0.29 \pm 0.03$ & $0.25 \pm 0.04$ \\
\hline Calcium & $118 \pm 6$ & $112 \pm 19$ \\
\hline Rubidium & $6.14 \pm 0.09$ & $6.59 \pm 0.45$ \\
\hline Sodium & $6.6 \pm 0.8$ & $6.1 \pm 1.5$ \\
\hline
\end{tabular}




\section{Discussion}

The FDA Food and Drug Administration (USA) has published results on arsenic in apple juice (ready to drink) of domestic (North American) market: five percent of the 94 apple juice samples were above $10 \mathrm{~g} . \mathrm{g}^{-9}$ of total arsenic, data obtained using ICP-MS (Inductively coupled plasma mass spectrometry). In a memorandum from the Department of Health and Human Services - Chemical Hazard Assessment Team, Office of Food Safety (HFS-301), FDA affirms that the chronic consumption of apple juice products containing over the level of concern $\left(L O C=23 \mu \mathrm{g} . \mathrm{L}^{-1}\right.$ or g.g $\left.\mathrm{g}^{-9}\right)$ of total arsenic would represent a potential health risk ${ }^{20}$. The same LOC could be applied for different types of juices and beverages, for instance pear juice. In a different survey from 2008 using ICP-MS some samples of concentrated pear juice

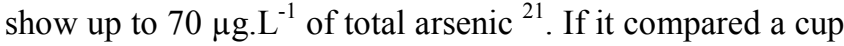
of coffee prepared with a $100 \mathrm{mg}$ of hot water, 1 rounded tablespoon ( 7.5 grams with less than 1.0 gram passing the paper filter) of coffee and 2 rounded tablespoon 15.0 grams of sugar cane from this study, considering a hypothetical amount of 0.0 g. $\mathrm{g}^{-9}$ arsenic in both water and coffee, this hypothetical cup of coffee would present $13 \mu \mathrm{g} . \mathrm{L}^{-1}$ (or g.g $\mathrm{g}^{-9}$ ) of inorganic arsenic only due to sugar cane, half of the LOC $=23 \mu \mathrm{g} . \mathrm{L}^{-1}$ or $\mathrm{g} \cdot \mathrm{g}^{-9}$ of total arsenic.

The odd presence of uranium and rare earth elements such lanthanum and samarium in sugar cane could be explained due the fact of phosphate fertilizers (monazite and rock phosphate for instance) are used in crop yielding; these rock fertilizers present significant amounts of uranium and RREs 17. Apparently, metabolism of some nutrients in plants is increased by rare earth elements. RREs are responsible for the transfer of $\mathrm{N}$ from inorganic to organic form, which is beneficial for protein synthesis and regulation of nutrient balance in plants ${ }^{22}$.

Many studies such the USDA Data Library ${ }^{3}$ point out the fact of sugar is not an important source of any essential element or vitamins. Results strength the term 'empty calories' what often is used to refer sugar (and solid fats) ${ }^{23}$. One example of the lack of essential elements in sugar cane is the low concentration found for calcium (one of the most important element in man and animal lives), $\mathrm{Ca}=84.8 \pm 7.9$ $\mathrm{mg} / 100 \mathrm{~g}$ in sugar, which is in accordance with the value of $83.0 \mathrm{mg} / 100 \mathrm{~g}$ as calcium concentration in the sugar brown reported in the Basic Report from the National Agricultural Library $\mathrm{NAL}^{3}$. Sodium concentration observed in this study $\left(\mathrm{Na}=262 \pm 30 \mathrm{~g} \cdot \mathrm{g}^{-6}\right.$ in sugar) is in compliance with NAL USDA data $\mathrm{Na}=280 \mathrm{~g}^{\mathrm{g}} \mathrm{g}^{-6}$ in sugar brown ${ }^{3}$. In fact, $\mathrm{Na}$ is an essential element with a limited ingestion up to 2400 mg.day ${ }^{-1}$ (equivalent to 8 kilograms of sugar or 6.0 grams of table salt Sodium Chloride) to be considered as safe. Upper values are associated to heart and kidney diseases ${ }^{7}$. Hence, sugar is not a major source of sodium in a healthy diet.

For different commodities like rice (what is not an empty calorie itself), fortification programmes are already a reality. Muthayya ${ }^{24}$ point out' There are opportunities to fortify a significant share of rice that comes from large mills supplying centralized markets and national welfare programs in major rice-growing countries. (...) The cost of fortifying rice is only $1.5 \%$ to $3 \%$ of the current retail price of rice. Countries that mandate rice fortification have the strongest evidence for achieving wide coverage and impact ${ }^{24}$.

In fact, the role of sugar as an efficient vehicle for fortification with vitamin $\mathrm{A}$ is already a well-stablished technology ${ }^{25}$. Concerning mineral fortification of sugar, there are different conclusions for different initiatives. In Guatemala during the mid-1970s, a trial on fortification of sugar with NaFeEDTA was carried out. At the time, the product appeared to be promising, showing an apparent absorption of $3 \%$ to $8 \%$. Sugar was fortified by directly adding $1 \mathrm{~g}$ of the chelate per kilogram of sugar. However, after four years of consumption of this fortified sugar in three selected communities, the change in iron nutrition was only marginal. Significant increase in the urinary excretion of zinc, copper, and iron was observed. Recently, iron tris-glycine chelate, a new tasteless chelate in which iron is chelated with three molecules of glycine has been used successfully to fortify sugar in Brazil. With the tris-glycine chelate, there are no organoleptic changes, to the point that it can be used in caster sugar ${ }^{26}$.

\section{Conclusions and Recommendations}

Sugar cane is really an 'empty calories' food additive, in terms of essential elements (such calcium) in man and animal nutrition. It should be discussed among public and private stakeholders how pertinent and reliable could be the adoption of policies like fortification of sugar with minerals, policy proposed and reported during the WHO - World Health Organization - Global Nutrition Policy Review (GNPR) 2009-2010 27.

Nevertheless, fortification programmes to improve mineral properties on sugar should not promote increased consumption of sugar itself, since sugar cane presents hazardous elements as observed in this study, besides the fact of high consumption of sugar leads to obesity and diabetes.

When we ingest a food or drink, the nutrients contained are released from a complex matrix, absorbed into the bloodstream and transported to their respective target tissues. However, not all nutrients can be utilized to the same extent. In other words, they differ in their bioavailability. Understanding nutrient bioavailability helps optimize diet formulations and set appropriate nutrient recommendations. Regarding main human health, the bioavailability of a nutrient is governed by external and internal factors. External factors include the food matrix and the chemical form of the nutrient in question, whereas gender, age, nutrient status and life stage (e.g., pregnancy, labor, exercising) are among the internal factors.

Because aspects such as nutrient status also determine whether and how much of a nutrient is actually used, stored or excreted. 


\section{Acknowledgements}

This project is partially supported by: by the Minas Gerais state-owned Scientific supporter Agency FAPEMIG. We appreciate every effort from CDTN/CNEN during $\mathrm{Mr}$. Avelar's Post-Doc internship at the institute in order to carry-out the nuclear analyses.

\section{Disclaimer}

Statements and opinions expressed in this paper are those of the authors, and do not necessarily reflect the organizations with which the authors are affiliated. The authors disclaim any responsibility for such material and do not endorse any product, technology or equipment mentioned herein.

\section{REFERENCES}

[1] Chaudhary S, Gupta AK, Kumar L the Sedges and Grasses of Gautambudhnagar (Noida) U. P. India, International Multidisciplinary Research Journal. 2012; 2(3):45-48.

[2] Rastogi VB Modern Biology, 251 pages. $8^{\text {th }}$ Edition. New Delhi. Piyushi Publishers PVT.

[3] USDA United States Department of Agriculture, National Agricultural Library, Basic Report for Sugar, from [http://ndb.nal.usda.gov/ndb/foods/show/6091?fg $=\& m a n=\& 1$ facet $=\&$ count $=\& \max =25 \&$ qlookup $=$ sugar $\&$ offset $=\&$ sort $=\& \mathrm{f}$ ormat $=$ Abridged\&_action_show $=$ Apply + Changes $\& Q v=100$ $0 \& Q 11434=1.0 \& Q 11435=1.0 \& Q 11436=1.0 \& Q 11437=1.0$ ], accessed in [12/11/2014].

[4] FAO Food and Agriculture Organization Sugar Beet White Sugar - Agribusiness Handbook. Roma; FAO; 2009.

[5] OECD-FAO Organisation for Economic Co-operation and Development, Food and Agriculture Organization. Agricultural Outlook 2011-2020, OECD/FAO 2012 Chapter 6: Sugar, 2011, pages 119-132 (296 pages). Extraide de [http://www.oecd.org/site/oecd-faoagriculturaloutlook/48184 295.pdf, ISBN 978-92-64-17307-1], Accessed in [27/09/2014]

[6] CONAB Companhia Nacional de Abstecimento, (Brazilian) National Food Supply Company, Acompanhamento da Safra Brasileira Cana de Açúcar 2012/2013 (In Portuguese), Monitoring of the Brazilian Sugarcane Harvest 2012/2013, Brasilia, 18 pages, 2012. Extraide de [http://www.conab.gov.br/OlalaCMS/uploads/arquivos/12 1 $2 \quad 12 \quad 1034 \quad 43$ boletim cana portugues_12 2012.pdf], acessed in $[11 / \overline{1} 0 / 2014]$.

[7] Lustig RH Fat Chance Beating the Odds against Sugar, Processed Food, Obesity, and Disease; New York: Hudson Street Press; 2012.

[8] Malik VS, Schulze MB, Hu FB Intake of sugar-sweetened beverages and weight gain: A systematic review. American Journal of Clinical Nutrition. 2006; 84: 274-88.
[9] NYCG New York City Government, Notice of Public Hearing fom [http://www.nyc.gov/html/doh/downloads/pdf/ notice/2012/amend-food-establishments.pdf], accessed in [03/07/2013].

[10] Grynbaum M Health Panel Approves Restriction on Sale of Large Sugary Drinks, New York Times: New York, September 13, 2012. Page A24. 2012.

[11] Grynbaum M.M. Judge Blocks New York City's Limits on Big Sugary Drinks, New York Times: New York, March 11, 2013. Page A1. 2013

[12] Alexander L.M. , Rucker W. C. Encyclopedia of African American History - Volume 3, Santa Barbara, USA; 2010

[13] Fish J.M. What Does the Brazilian Census Tell Us About Race? Psychology Today, from [http://www.psychologytoda y.com/blog/looking-in-the-cultural-mirror/201112/what-does -the-brazilian-census-tell-us-about-race], accessed in [04/04/2013].

[14] Phillips T First London, The Guardian, World News., from [http://www.guardian.co.uk/world/2007/mar/09/brazil.renew ableenergy], accessed in [03/17/2013].

[15] Campbell J. A (2008) Growing Concern: Modern Slavery and Agricultural Production in Brazil and South Asia, Human Rights and Human Welfare, Topical Research Digest: Human Rights and Contemporary Slavery, Graduate School of International Studies: University of Denver, USA. Pages 131-141.

[16] (Avelar et al., 2015) Avelar A. C, Ferreira W. M., Menezes M.A.B.C., 2015. Dietary phosphate contribution to uranium deposition in rabbit shinbones. J. Radioanal. Nucl. Chem. 304, 1071-1076.

[17] Avelar AC, Ferreira WM, Menezes MABC Contribuição dos fertilizantes agrícolas para a dispersão de urânio no meio ambiente. Revista Saúde e Ambiente. 2007;37-42.

[18] Avelar AC, Ferreira WM, Brito W. Elementos tóxicos presentes em fosfatos, calcário e farinha de ossos. Rev. Bras. Saúde Prod. An, 2011;.12,709-717 .

[19] Menezes MABC, Jacimovic R Optimised k0-instrumental neutron activation method using the TRIGA MARK I IPR-R1 reactor at CDTN/CNEN, Belo Horizonte, Brazil. Nuclear Instruments \& Methods in Physics Research. Section A, 564:707-715, 2006.

[20] FDA DEPARTMENT OF HEALTH \& HUMAN SERVICES Memorandum 15 December 2008. From [http://www.fda.go v/Food/FoodborneIllnessContaminants/Metals/ucm277681.h $\mathrm{tm}]$, accessed in [03/07/2013].

[21] FDA DEPARTMENT OF HEALTH \& HUMAN SERVICES Memorandum 08 April 2008. fFom [http://www.fda.gov/Foo d/FoodborneIllnessContaminants/Metals/ucm277676.htm] accessed in [03/07/2013].

[22] Challaraj ES, Ramachandran AM, David RA., Natesan M, Maruthamuthu S. Effect of some rare earth elements on dry matter partitioning, nodule formation and chlorophyll content in Arachis hypogaea L. plants Australian Journal of Crop Sciences. 2010;4(9):670-675

[23] USDA United States Department of Agriculture, What are empty calories? From [http://www.choosemyplate.gov/weig ht-management-calories/calories/empty-calories.html], accessed in [07/03/2013]. 
[24] Muthayya S, Hall J, Bagriansky J, Sugimoto J, Gundry D, et al. Rice fortification: An emerging opportunity to contribute to the elimination of vitamin and mineral deficiency worldwide Food \& Nutrition Bulletin, 33(4);296-307, 2012.

[25] Kawuma M. Sugar as a potential vehicle for vitamin A fortification: Experience from Kamuli district in Uganda, African Health Sciences. 2002, 2(1): 11-15.
[26] UNU United Nations University Fortification of sugar with vitamin A From [http://archive.unu.edu/unupress/food/V192 e/ch07.htm\#b8Fortification\%20of\%20sugar\%20with\%20ir], accessed in 07/03/2014

[27] WHO World Health Organization, Global database on the Implementation of Nutrition Action (GINA). Extraído de [https://extranet.who.int/nutrition/gina/es/node/10868], accessed in $11 / 12 / 2014$. 